\title{
Setaphyes elenae sp. nov., a new species of mud dragon (Kinorhyncha: Allomalorhagida) from Skagerrak (north-eastern Atlantic Ocean)
}

\author{
Diego CEPEDA ${ }^{1}$, Alberto GONZÁLEZ-CASARRUBIOS ${ }^{2, *}$, \\ Nuria SÁNCHEZ ${ }^{3} \&$ Fernando PARDOS ${ }^{4}$ \\ ${ }^{1,2,4}$ Universidad Complutense de Madrid (UCM), Faculty of Biological Sciences, Department of \\ Biodiversity, Ecology and Evolution. C/ José Antonio Novais 12. 28040 Madrid, Spain. \\ ${ }^{3}$ Institut Français de Recherche pour l'Exploitation de la Mer (IFREMER), Deep-sea Laboratory. \\ ZI de la Pointe du Diable. 29280 Plouzané, France. \\ *Corresponding author: albert23@ucm.es \\ 1Email: diegocepeda@ucm.es \\ ${ }^{3}$ Email: Nuria.Sanchez.Santos@ifremer.fr \\ Email: fpardos@ucm.es

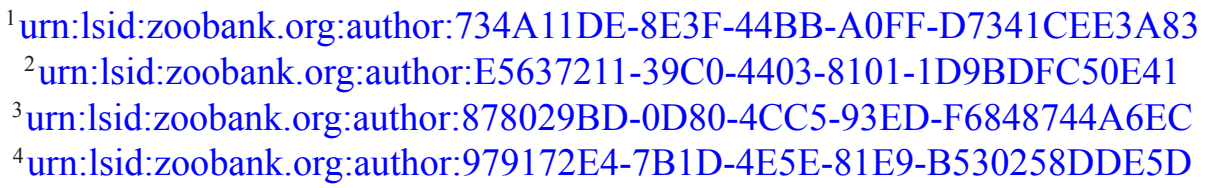

\begin{abstract}
Meiofauna sampling in the proximity of Syd-Hällsö Island (Strömstad, Sweden) revealed a new species of Kinorhyncha from the Skagerrak. The species, Setaphyes elenae sp. nov., is distinguished from its congeners by the arrangement of the middorsal cuticular specializations (it has shortened, distally rounded middorsal processes on segments 1 and 9 and middorsal elevations throughout segments 2-8), as well as by the presence of paired laterodorsal setae on segments 3, 5, 7 and 9 and ventromedial setae on segments 3, 5 and 7 in both males and females. The finding of a new species from the northeastern Atlantic Ocean, provides new valuable information for the recently established genus in the Allomalorhagida.
\end{abstract}

Keywords. Meiofauna, taxonomy, Scalidophora, biodiversity, invertebrates.

Cepeda D., González-Casarrubios A., Sánchez N. \& Pardos F. 2020. Setaphyes elenae sp. nov., a new species of mud dragon (Kinorhyncha: Allomalorhagida) from Skagerrak (north-eastern Atlantic Ocean). European Jopurnal of Taxonomy 637: 1-15. https://doi.org/10.5852/ejt.2020.637

\section{Introduction}

The phylum Kinorhyncha Reinhard, 1887 encompasses a group of meiobenthic, free-living invertebrates that mainly inhabit the upper centimetres of marine and estuarine sediments, although some species have been found living in hard substrata or associated with macroalgae and marine phanerogams (Higgins 1988). Kinorhynchs have been described from shallow to deep-sea waters across the worldwide oceans, 
but certain areas have received much more attention to the detriment of others due to the specialists sampling strategies (Sánchez et al. 2012; Neuhaus 2013; Sørensen et al. 2013; Cepeda et al. 2019).

Kinorhynch biodiversity of the North Sea, together with other north-eastern Atlantic areas nearby, has been studied earlier (Neuhaus, 2013). Currently, 20 species are known in this area: Campyloderes vanhoeffeni Zelinka, 1913, Centroderes spinosus (Reinhard, 1881), Condyloderes multispinosus (McIntyre, 1962), Echinoderes dujardinii Claparède, 1863, E. elongatus (Nyholm, 1947), E. higginsi Huys \& Coomans, 1989, E. levanderi Karling, 1955, E. peterseni Higgins \& Kristensen, 1988, E. setiger (Greeff, 1869), E. subfuscus Zelinka, 1928, E. worthingi Southern, 1914, Paracentrophyes quadridentatus (Zelinka, 1928), Pycnophyes calmani (Zelinka in Southern, 1914), P. communis Zelinka, 1908, P. zelinkaei Southern, 1914, Semnoderes armiger Zelinka, 1928, Setaphyes dentatus (Reinhard, 1881), S. flaveolatus (Zelinka, 1928), S. kielensis (Zelinka, 1928) and Zelinkaderes submersus (Gerlach, 1969) (Zelinka 1928; Nyholm 1947; McIntyre 1962, 1964; Gerlach 1969; Huys \& Coomans 1989; Sørensen et al. 2009; Neuhaus et al. 2013; Altenburger 2016).

In the context of global change and decreasing studies of taxonomy, especially those of small-sized taxa, there is a need to improve taxonomic information about meiofaunal organisms, even in geographic areas that are supposed to be relatively well-studied (Mora et al. 2011; Sørensen \& Grzelak 2018). A recent sampling done in the proximities of Syd-Hällsö Island (Strömstad, Sweden) revealed a new species of Kinorhyncha from Skagerrak. Additionally, the species Echinoderes cf. eximus and Pycnophyes ancalagon Sørensen \& Grzelak, 2018, the latter recently described from the Svalbard Archipelago (Arctic Ocean), are firstly reported for the boreal area.

\section{Material and methods}

\section{Study site}

Sampling was undertaken at a single locality near Syd-Hällsö Island (Strömstad, Sweden) during summer 2017, at the eastern-most limit of the North Sea: $58^{\circ} 56.846^{\prime} \mathrm{N}, 11^{\circ} 4.896^{\prime} \mathrm{E}$ (Fig. 1B). This area encompasses the Skagerrak Strait that connects the North Sea with the Kattegat sea region (Fig. 1A).

Skagerrak, with a surface area of about $32000 \mathrm{~km}^{2}$, is the deepest area of the North Sea basin, with a maximum depth of $700 \mathrm{~m}$ (Weering et al. 1993; Rosenberg et al. 1996). Skagerrak is dominated by a deep-reaching flow of water from the central and northern North Sea, with a salinity of about 35 psu and to a lesser extent by a weaker inflow from the southern North Sea with a salinity of about 31-34 psu influenced by river inputs (Rosenberg et al. 1996). Additionally, the shallowest waters of Skagerrak are also subject of upwelling events that cause low-saline currents along the Swedish and Norwegian coastlines (Rodhe 1996).

Skagerrak forms a natural topographic sediment trap, receiving inputs from the entire north-western European drainage systems and the North Sea shoreline (Weering et al. 1993). Thus, Skagerrak has been evidenced as a major depository of fine-grained sediments in the North Sea, with $59 \%$ of particles with an average size less than $63 \mu \mathrm{m}$ (Weering et al. 1987). Nevertheless, areas with coarse gravel, sandy coves and sandbars are also present in the area (Curini-Galletti et al. 2012).

\section{Sampling and specimen preparation}

Sampling was done during the summer of 2017 by dredging. The collected sample was taken at a depth of 55-65 m and mainly consisted of very fine, soft mud. Sediment was kept in large plastic boxes and stored at a constant temperature of $15^{\circ} \mathrm{C}$. Meiofaunal organisms were then extracted by $\mathrm{MgCl}_{2}-$ decantation and live material was studied and sorted using stereo microscopes. 
Kinorhynchs were preserved in $100 \%$ ethanol. For light microscopy (LM), unmounted specimens were dehydrated through a graded series of glycerine. After being kept in $100 \%$ glycerine for $24 \mathrm{~h}$, kinorhynchs were mounted on glass slides with Fluoromount $G^{\circledR}$ sealed with Depex ${ }^{\circledR}$. Mounted specimens were studied with an Olympus ${ }^{\circ}$ BX51-P microscope with differential interference contrast (DIC) optics equipped with an Olympus ${ }^{\odot}$ DP-70 camera. Identification to genus level was done using the dichotomous keys provided by Sørensen \& Pardos (2008) for cyclorhagids and the genus diagnoses provided by Sánchez et al. (2016) for allomalorhagids. For scanning electron microscopy (SEM), some unmounted kinorhynchs were sonically cleaned during 10-15 s and led to chemical point drying using a hexamethyldisilazane-ethanol series. Finally, specimens were coated with gold and mounted on aluminium stubs to be studied with a JSM ${ }^{\circledR}$ 6335-F JEOL SEM at the ICTS Centro Nacional de Microscopía Electrónica (UCM, Spain). Type material was deposited at the Natural History Museum of Denmark (NHMD). Line drawings and image plates composition were done using Adobe ${ }^{\circledR}$ Photoshop and Illustrator CC-2014 software.

\section{Morphometric statistical analyses}

Differences in selected morphometric measures (total trunk length, standard width and lateral terminal spines' length) of Setaphyes elenae sp. nov. and its congeners were tested. For this, we selected several specimens of $S$. dentatus $(\mathrm{n}=18)$ and $S$. flaveolatus $(\mathrm{n}=14)$, which are the most morphologically similar, and are also distributed through the north-eastern Atlantic Ocean. Specimens of S. dentatus and S. flaveolatus are from several Atlantic and Mediterranean locations surrounding the Iberian Peninsula, stored at the Meiofauna Collection of the UCM.

Normality and homoscedasticity of the variables were tested using the Saphiro-Wilk's test (together with visual methods of density and Q-Q plots) and the Bartlett's test, respectively. Tukey multiple comparison test and pairwise comparisons between group levels with corrections for multiple testing were used to determine which means amongst the set of means differ from the rest. A one-way analysis of variance (ANOVA) was used to test differences, but when heteroscedasticity was detected, a Welch's

A

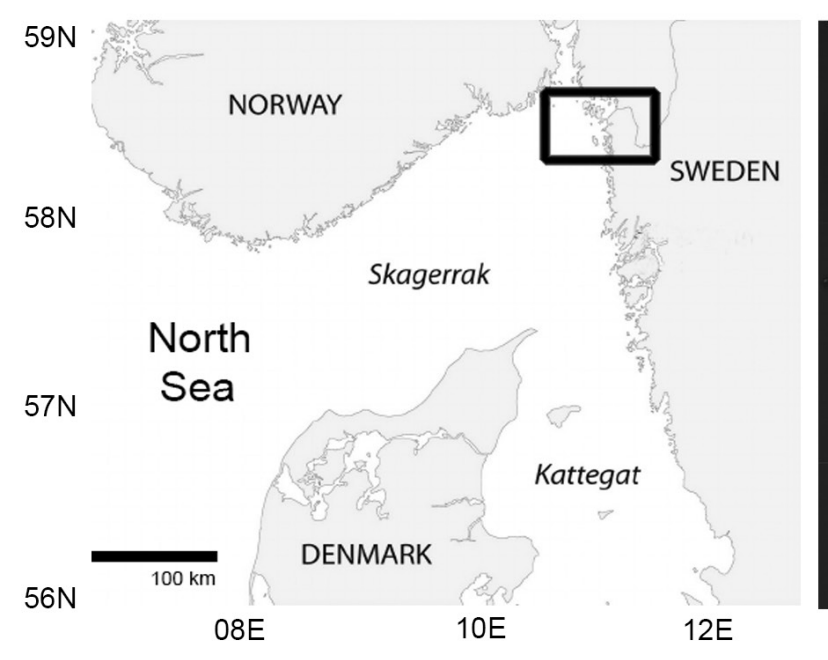

B

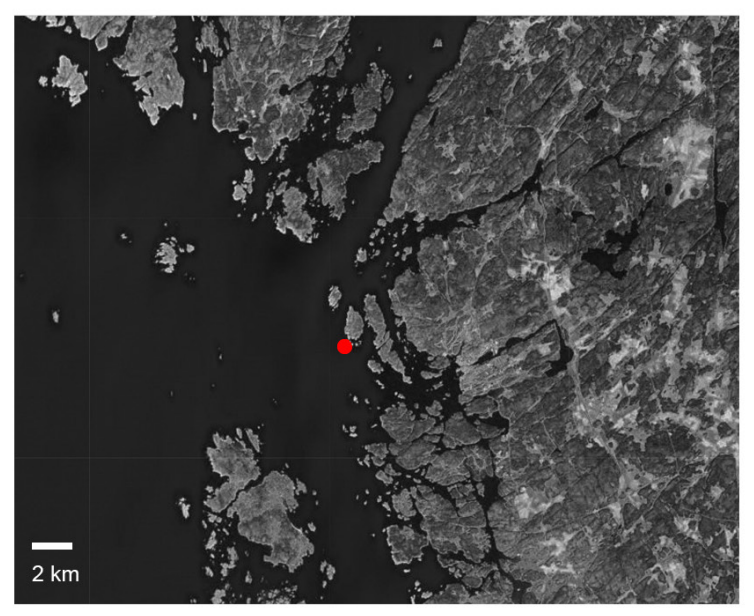

Fig. 1. A. Map showing the sampling area of Syd-Hällsö Island (Strömstad, Sweden). B. Detail. Red point shows the specific sampling point. 
ANOVA was performed instead. All the statistical analyses were run in R ver. 1.1.453 using the 'stats' basic package and the 'car' package ver. 3.0.5 (Fox et al. 2019).

\section{Results}

Five species co-occurr in the collected sample near Syd-Hällsö Island (Swedish North Sea): Centroderes spinosus, Echinoderes cf. eximus, Pycnophyes ancalagon, Semnoderes armiger and Setaphyes elenae sp. nov.

Class Allomalorhagida Sørensen et al., 2015

Family Pycnophyidae Zelinka, 1896

Genus Setaphyes Sánchez et al., 2016

Setaphyes elenae sp. nov. urn:1sid:zoobank.org:act:6C4FE50F-E39A-451E-B805-60B709B9B9B4

Figs 2-4, Tables 1-3

\section{Diagnosis}

Setaphyes with shortened, distally rounded middorsal processes on segments 1 and 9, and middorsal elevations on segments 2-9, superficially covered by tufts of elongated, thick hairs whose tips sometimes surpass the posterior margin of segment. Unpaired setae in paradorsal position on segments 1-9. Laterodorsal setae on segments 3, 5, 7 and 9; paralateral setae absent. Lateroventral setae on segments 2-10. Ventromedial setae on segments 3, 5 and 7. Paired, small, dot-shaped intracuticular structures (maybe outlets of glandular cells) present in several positions throughout the trunk, with a specific arrangement that differs from males to females. Males with paired, sexually dimorphic ventromedial tubes on segment 2 , and females with paired, sexually dimorphic ventrolateral setae on segment 2. Lateral terminal spines present, relatively short, slender. Segment 11 retractable into segment 10 .

\section{Etymology}

The species is dedicated to Ms Elena González, sister of the second author.

\section{Material examined}

\section{Holotype}

ATLANTIC OCEAN • + adult (mounted in Fluoromount $G^{\circledR}$ ); near Syd-Hällsö Island, Skagerrak (Fig. 1B); 58 56.846' N, 11 ${ }^{\circ} 4.896^{\prime} \mathrm{E}$; 55-65 m depth; Ulf Jondelius and Fredrik Pleijel leg.; very fine mud; NHMD 655358.

\section{Paratypes}

ATLANTIC OCEAN $\bullet 3$ adult $\lesssim \widehat{\partial}, 2$ adult $q+q$ (all mounted in Fluoromount $\mathrm{G}^{\circledR}$ ); same collection data as for holotype; NHMD 655359 to 655363.

\section{Additional non-type material}

ATLANTIC OCEAN • 8 specs (four mounted for LM and four mounted for SEM); same collection data as for holotype; Meiofauna Collection UCM.

\section{Description}

See Table 1 for measurements and dimensions, Table 2 for summary of cuticular elevation, process, seta, tube, nephridiopore and sensory spot locations, and Table 3 for summary of intracuticular, dot-shaped structure locations. 
Table 1. Measurements of nine adult specimens of Setaphyes elenae sp. nov. (four males and five females) from Skagerrak. Abbreviations: LTS = lateral terminal spines; MSW = maximum sternal width (measured at segment 5); $\mathrm{S}=$ segments' length (followed by number of corresponding segment); $\mathrm{Sd}=$ standard deviation; SSW = standard sternal width (measured at segment 10); TL = total length.

\begin{tabular}{|c|c|c|c|c|c|c|c|}
\hline Character & Range $q$ & Mean $q$ & Range $\widehat{\partial}$ & Mean $\widehat{\delta}$ & Total range & Total mean & Sd \\
\hline $\mathrm{TL}(\mu \mathrm{m})$ & $612.67-722.64$ & 679.192 & $614.32-647.86$ & 625.51 & $612.67-722.64$ & 655.33 & 44.06 \\
\hline MSW-5 $(\mu \mathrm{m})$ & $179.55-188.89$ & 183.422 & $168.06-176.25$ & 170.72 & $168.06-188.89$ & 177.78 & 7.61 \\
\hline MSW-5/TL (\%) & $26-29.5$ & 27 & $26.2-28.4$ & 27.3 & $26-29.5$ & 27.2 & 1.22 \\
\hline $\mathrm{SSW}(\mu \mathrm{m})$ & $141.41-152.44$ & 144.178 & $124.68-133.65$ & 131.065 & $124.68-152.44$ & 138.35 & 8.23 \\
\hline SSW/TL (\%) & $19.7-23$ & 21.3 & $19.2-21.9$ & 21 & $19.2-23$ & 21.1 & 1.14 \\
\hline $\mathrm{S} 1(\mu \mathrm{m})$ & $87.74-108.41$ & 96.584 & $89.16-96.28$ & 91.548 & $87.74-108.41$ & 94.35 & 6.31 \\
\hline $\mathrm{S} 2(\mu \mathrm{m})$ & $59.74-82.08$ & 69.712 & $62.45-68.07$ & 65.068 & $59.74-82.08$ & 67.65 & 6.42 \\
\hline $\mathrm{S} 3(\mu \mathrm{m})$ & $57.56-79.22$ & 70.068 & $63.54-68.8$ & 66.655 & $57.56-79.22$ & 68.55 & 6.04 \\
\hline $\mathrm{S} 4(\mu \mathrm{m})$ & $70.27-79.51$ & 74.618 & $68.79-81.68$ & 74.51 & $68.79-81.68$ & 74.57 & 4.48 \\
\hline $\mathrm{S} 5(\mu \mathrm{m})$ & $69.77-83.01$ & 77.1 & $69.3-76.08$ & 74.438 & $69.3-83.01$ & 75.92 & 5.84 \\
\hline $\mathrm{S} 6(\mu \mathrm{m})$ & $73.96-81.58$ & 78.504 & $73.81-83.53$ & 77.013 & $73.81-83.53$ & 77.84 & 3.51 \\
\hline $\mathrm{S} 7(\mu \mathrm{m})$ & $74.47-85.94$ & 80.752 & $73.33-80.37$ & 75.385 & $73.33-85.94$ & 78.37 & 4.70 \\
\hline $\mathrm{S} 8(\mu \mathrm{m})$ & $69.57-86.82$ & 80.846 & $77.08-79.98$ & 78.138 & $69.57-86.82$ & 79.64 & 5.31 \\
\hline $\mathrm{S} 9(\mu \mathrm{m})$ & $70.24-84.44$ & 79.61 & $68.76-78.56$ & 74.463 & $68.76-84.44$ & 77.32 & 5.43 \\
\hline $\mathrm{S} 10(\mu \mathrm{m})$ & $64.87-77.97$ & 73.66 & $60.93-71.98$ & 67.165 & $60.93-77.97$ & 70.77 & 5.92 \\
\hline $\mathrm{S} 11(\mu \mathrm{m})$ & $27.93-39.81$ & 32.3 & $27.49-34.23$ & 30.615 & $27.49-39.81$ & 31.55 & 3.74 \\
\hline LTS $(\mu \mathrm{m})$ & $90.64-105.7$ & 100.9 & $149.06-168.74$ & 158.928 & $90.64-168.74$ & 126.69 & 31.29 \\
\hline LTS/TL (\%) & $13.9-15.8$ & 14.9 & $24-26$ & 25.4 & $13.9-26$ & 19.6 & 5.60 \\
\hline
\end{tabular}

Head with retractable mouth cone and introvert. The collected specimens were not suitable for head examinations, hence data on number and arrangement of scalids and oral styles are not available.

Neck with four dorsal and two ventral sclerotized placids (Fig. 2A-B, D). Dorsal placids rectangular, with a slightly convex anterior margin; mesial ones broader than lateral ones (Fig. 2B). Ventral placids morphologically similar to dorsal ones but much more elongated, getting thinner towards the lateral sides (Fig. 2A, D).

Trunk with eleven segments (Figs 2A-B, 3A, H, 4A). Segment 1 with one tergal, two episternal and one sub-trapezoidal, midsternal plate; remaining ones with one tergal and two sternal cuticular plates (Figs 2A-D, 3A, H). Tergal cuticular plates slightly bulging middorsally. Sternal plates reach their maximum width at segment 5 , but are almost constant in width across the trunk, slightly tapering at the last three trunk segments (Figs 2A-B, 3A, H). Sternal cuticular plates are relatively narrow in the ratio maximum width to total trunk length (MSW-5: TL average ratio $=27.2 \%$ ), giving the animal a slender appearance (Figs 2A-B, 3A, H, 4A). Middorsal processes on segments 1 and 9, shortened and distally rounded (Figs 2B, 3B, M, 4G, I); middorsal elevations on segments $2-8$, pentagonally-shaped, distally rounded, with intracuticular, butterfly-like atria of paradorsal sensory spots (Figs 2B, 3D, F, I, K, 4B, E). Middorsal elevations superficially covered by tufts of elongated, thick cuticular hairs whose tips 
A
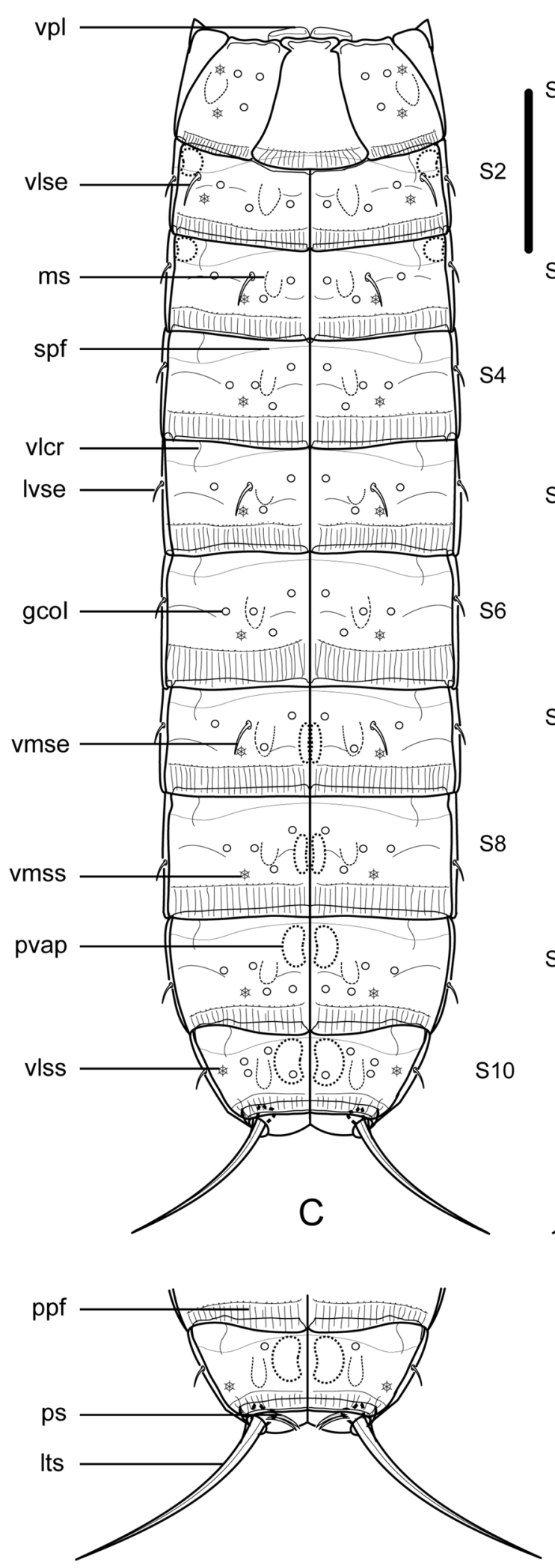

B
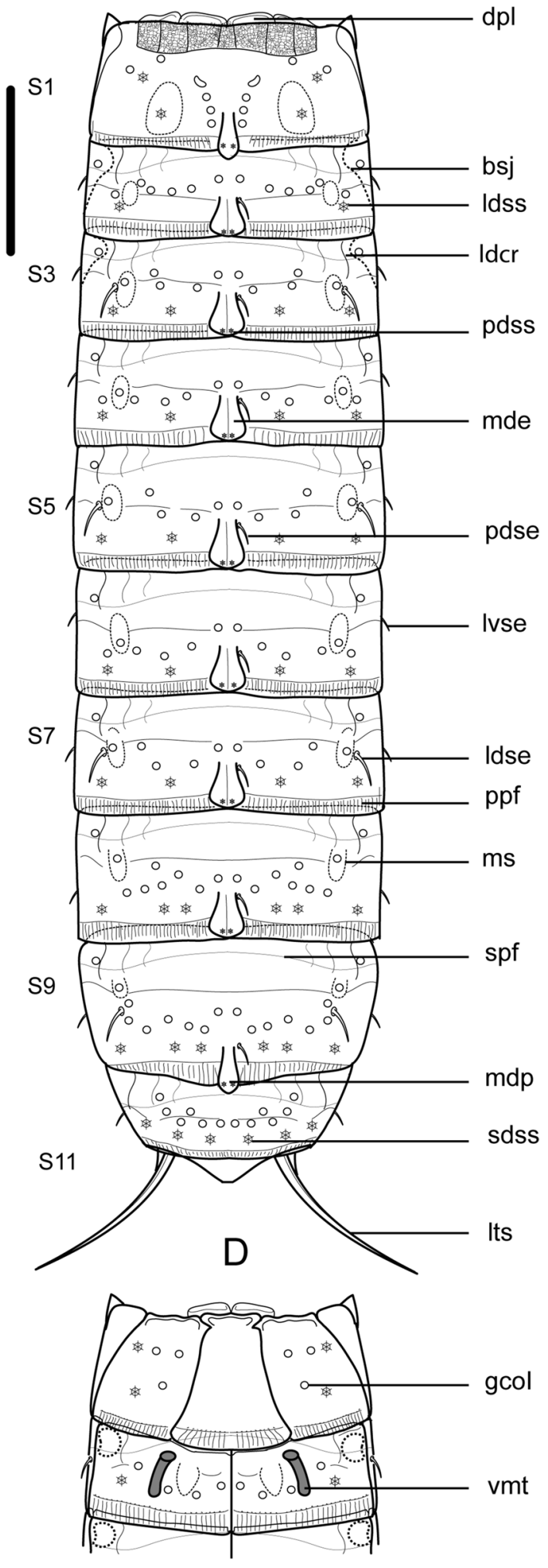
Table 2. Summary of nature and arrangement of cuticular elevations, processes, spines, tubes, setae, sensory spots and nephridiopores in Setaphyes elenae sp. nov. Abbreviations: ce = cuticular elevation; $\mathrm{cp}=$ cuticular process; $\mathrm{LD}=$ laterodorsal; 1 ts $=$ lateral terminal spine; $\mathrm{LV}=$ lateroventral; $\mathrm{MD}=$ middorsal; ne = nephridiopore; $\mathrm{PD}=$ paradorsal; $\mathrm{SD}=$ subdorsal; $\mathrm{se}=$ seta; $\mathrm{ss}=$ sensory spot; $\mathrm{tu}=$ tube; $\mathrm{VL}=$ ventrolateral; $\mathrm{VM}=$ ventromedial. ${ }^{*}$ indicates unpaired structures.

\begin{tabular}{clcccccc}
\hline Segment & MD & PD & SD & LD & LV & VL & VM \\
\hline 1 & $\mathrm{cp}^{*}$ & $\mathrm{ss}$ & $\mathrm{ss}$ & $\mathrm{ss}$ & & $\mathrm{ss}, \mathrm{ss}$ & \\
2 & $\mathrm{ce}^{*}$ & $\mathrm{se}^{*}, \mathrm{ss}$ & & $\mathrm{ss}$ & $\mathrm{se}$ & $\mathrm{se}(+)$ & $\mathrm{ss}, \mathrm{tu}($ ð) \\
3 & $\mathrm{ce}^{*}$ & $\mathrm{se}^{*}, \mathrm{ss}$ & $\mathrm{ss}$ & $\mathrm{ss}, \mathrm{se}$ & $\mathrm{se}$ & & $\mathrm{se}, \mathrm{ss}$ \\
4 & $\mathrm{ce}^{*}$ & $\mathrm{se}^{*}, \mathrm{ss}$ & $\mathrm{ss}$ & $\mathrm{ss}$ & $\mathrm{se}$ & & $\mathrm{ss}$ \\
5 & $\mathrm{ce}^{*}$ & $\mathrm{se}^{*}, \mathrm{ss}$ & $\mathrm{ss}$ & $\mathrm{ss}, \mathrm{se}$ & $\mathrm{se}$ & $\mathrm{se}, \mathrm{ss}$ \\
6 & $\mathrm{ce}^{*}$ & $\mathrm{se}^{*}, \mathrm{ss}$ & $\mathrm{ss}$ & $\mathrm{ss}$ & $\mathrm{se}$ & $\mathrm{ss}$ \\
7 & $\mathrm{ce}^{*}$ & $\mathrm{se}^{*}, \mathrm{ss}$ & $\mathrm{ss}$ & $\mathrm{ss}, \mathrm{se}$ & $\mathrm{se}$ & $\mathrm{se}, \mathrm{ss}$ \\
8 & $\mathrm{ce}^{*}$ & $\mathrm{se}^{*}, \mathrm{ss}$ & $\mathrm{ss}, \mathrm{ss}$ & $\mathrm{ss}$ & $\mathrm{se}$ & & $\mathrm{ss}$ \\
9 & $\mathrm{cp}^{*}$ & $\mathrm{se}^{*}, \mathrm{ss}$ & $\mathrm{ss}, \mathrm{ss}$ & $\mathrm{ss}, \mathrm{se}$ & $\mathrm{se}, \mathrm{ne}$ & & $\mathrm{ss}$ \\
10 & & & $\mathrm{ss}, \mathrm{ss}$ & $\mathrm{ss}$ & $\mathrm{se}$ & $\mathrm{ss}$ & \\
11 & & & & & lts & & \\
\hline
\end{tabular}

sometimes surpass the posterior margin of the segments (Fig. 4B, E). Intracuticular, minute, dot-shaped, rounded to oval structures (maybe outlets of glandular cells) throughout the cuticle on segments 1-10 (Figs 2A-D, 3B-G, I-N). Location and pairs of these structures per segment differ from males to females (Table 3), and deviations from the bilateral symmetry of their arrangement have been observed in some specimens. Up to three pairs of conspicuous laterodorsal cuticular ridges on segments 2-10 (Figs 2A$\mathrm{B}, 3 \mathrm{D}-\mathrm{G}, \mathrm{I}-\mathrm{N})$. Cuticular hairs acicular, elongated, emerging from oval perforation sites, distributed all over the trunk cuticle. Pachycycli and ball-and-socket joints only conspicuous on segments 2-3, reduced on posterior segments (Fig. 2A-B, D). Apodemes on segments 7-10 (Fig. 2A-C). Primary pectinate fringe finely serrated; secondary pectinate fringe as a double tranverse, hairy-like, wavy row; free flaps covering the anterior part of subsequent segment (Figs 2A-D, 4D). Muscular scars as rounded to oval, hairless areas in laterodorsal and ventromedial positions on segments 1-10 (those of segment 1 in subdorsal and ventrolateral positions), quite inconspicuous (Fig. 2A-D).

Segment 1 with shortened, distally rounded middorsal process still extending beyond the posterior margin of segment (Figs 2B, 3B, 4G). Anterolateral margins of the tergal plate as horn-shaped, short, wide, distally curved and pointed extensions (Figs 2A-B, D, 3A-C, H, 4A). Anterior margin of segment with a reticule-like ornamentation dorsally (Figs 2B, 3B, 4C). Setae absent. Two pairs of sensory spots

Fig. 2 (opposite page). Line art illustrations of adult Setaphyes elenae sp. nov. A. + , ventral overview. B. + , dorsal overview. C. $\hat{\partial}$, segments 10-11, ventral view. D. $\hat{0}$, segments 1-2, ventral view. Abbreviations: $\mathrm{bsj}$ = ball-and-socket joint; $\mathrm{dpl}=$ dorsal placid; $\mathrm{gcoI}=$ type I glandular cell outlet; ldcr $=$ laterodorsal cuticular ridge; ldse = laterodorsal seta; ldss = laterodorsal sensory spot; 1 ts = lateral terminal spine; lvse $=$ lateroventral seta; $\mathrm{mde}=$ middorsal elevation; $\mathrm{mdp}=$ middorsal process; $\mathrm{ms}$ $=$ muscular scar; pdse $=$ paradorsal seta; pdss $=$ paradorsal sensory spot; $\mathrm{ppf}=$ primary pectinate fringe; ps = penil spine; pvap $=$ paraventral apodeme; sdss $=$ subdorsal sensory spot; $\mathrm{spf}=$ secondary pectinate fringe; vlcr $=$ ventrolateral cuticular ridge; vlse $=$ ventrolateral seta; vlss $=$ ventrolateral sensory spot; vmse $=$ ventromedial seta; vmss $=$ ventromedial sensory spot; $\mathrm{vmt}=$ ventromedial tube; $\mathrm{vpl}=$ ventral placid. Scale bar $=100 \mu \mathrm{m}$. 
Table 3. Summary of nature and arrangement of intracuticular structures (maybe outlets of glandular cells) in Setaphyes elenae sp. nov., including sexually dimorphic differences. Abbreviations: LD = laterodorsal; $\mathrm{PD}=$ paradorsal; $\mathrm{PL}=$ paralateral; $\mathrm{PV}=$ paraventral; $\mathrm{SD}=$ subdorsal; $\mathrm{VL}=$ ventrolateral; $\mathrm{VM}=$ ventromedial.

\begin{tabular}{|c|c|c|c|c|c|c|c|}
\hline Segment & PD & SD & LD & PL & VL & VM & PV \\
\hline 1 & $3 \times(+), 2 \times($ え) & $2 \times($ $), 1 \times($ え) & $1 \times(+), 2 \times($ ふ) & & $3 \times$ & & \\
\hline 2 & $1 \times$ & $2 \times$ & $3 \times(+), 1 \times(\widehat{\zeta})$ & & & $2 \times(+), 3 \times(\widehat{\zeta})$ & $1 \times$ \\
\hline 3 & $1 \times$ & $3 \times(+), 2 \times(\lesssim)$ & $1 \times$ & $1 \times$ & & $2 \times(+), 3 \times(\widehat{\zeta})$ & $1 \times$ \\
\hline 4 & $1 \times$ & $2 \times$ & 3× (ㅇ), 1×(ठ) & $1 \times$ & & $3 \times$ & $1 \times$ \\
\hline 5 & $1 \times$ & $3 \times(+), 2 \times\left(ठ^{\nwarrow}\right)$ & $2 \times$ & $1 \times$ & & $2 \times(+), 3 \times\left(ठ^{\nwarrow}\right)$ & $1 \times$ \\
\hline 6 & $1 \times$ & $2 \times$ & $3 \times(+), 1 \times\left(ठ^{\nwarrow}\right)$ & $1 \times$ & & $3 \times$ & $1 \times$ \\
\hline 7 & $1 \times$ & $3 \times(+), 2 \times(\overbrace{}^{\Uparrow})$ & $1 \times$ & $1 \times$ & & $2 \times(q), 3 \times\left(\zeta^{\lambda}\right)$ & $1 \times$ \\
\hline 8 & $1 \times$ & $5 \times($ $), 3 \times\left(ठ^{\nwarrow}\right)$ & $2 \times$ & $1 \times$ & & $3 \times$ & $1 \times$ \\
\hline 9 & $1 \times$ & $4 \times(\uparrow), 2 \times\left(\jmath^{\jmath}\right)$ & $3 \times(+), 1 \times(\overbrace{}^{\Uparrow})$ & $1 \times$ & & $3 \times$ & $1 \times$ \\
\hline 10 & $1 \times$ & $2 \times(q), 3 \times\left(ठ^{\lambda}\right)$ & $3 \times(+), 1 \times\left(ठ^{\Uparrow}\right)$ & & & $3 \times(q), 1 \times\left(\Xi^{\top}\right)$ & $1 \times(q)$ \\
\hline 11 & & & & & & & \\
\hline
\end{tabular}

in ventrolateral position longitudinally arranged, and one pair in paradorsal, subdorsal and laterodorsal positions (Figs 2A-B, D, 3B-C, 4G). Sensory spots on this and subsequent segments as oval areas with several rows of cuticular micropapillae surrounding a single pore (Fig. 4B, G, J).

Segment 2 with middorsal elevation not projecting beyond the posterior margin of segment (Figs 2B, $3 \mathrm{D}, 4 \mathrm{E})$. Unpaired seta in paradorsal position, on this and following segments indifferently located to the right or to the left of the middorsal cuticular specialization, not following any particular pattern, near the anterior margin of the segment (Figs 2B, 3D, 4E); paired setae in lateroventral position (Figs 2A-B, D, $3 \mathrm{E}$ ); females furthermore with paired, sexually dimorphic setae in ventrolateral position (Figs 2A, 3E). Sexually dimorphic male tubes in ventromedial position (Fig. 2D); detailed morphology of these tubes not determined. Paired sensory spots in paradorsal, laterodorsal and ventrolateral position, the latter near the ventrolateral-ventromedial limit, not longitudinally aligned with the following ventromedial sensory spots (Figs 2A-B, D, 3D-E).

Fig. 3 (opposite page). Light micrographs showing trunk overviews and details of cuticular trunk characters of $q$, holotype (NHMD 655358) (A-L, N) and ${ }^{\lambda}$, paratype (NHMD 655361) (M) of Setaphyes elenae sp. nov. A. Dorsal overview. B. Dorsal view on right half of segment 1. C. Ventral view on left half of segment 1. D. Dorsal view on right half of segment 2. E. Ventral view on left half of segment 2. F. Dorsal view on right half of segment 3. G. Ventral view on left half of segment 3. H. Ventral overview. I. Dorsal view on right half of segment 4. J. Ventral view on left half of segment 4. K. Dorsal view on right half of segment 8 . L. Ventral view on left half of segment 8. M. Dorsal view on right half of segment 9. N. Ventral view on left half of segment 9. Abbreviations: ldse = laterodorsal seta; lts = lateral terminal spine; $1 \mathrm{vse}=$ lateroventral seta mde $=$ middorsal elevation; mdp $=$ middorsal process; pdse $=$ paradorsal seta; $v l s e=$ ventrolateral seta; vmse $=$ ventromedial seta. Numbers after abreviations indicate correspong segment; sensory spots are marked as dashed circles, and glandular cell outlets as continuous circles. Scale bars: A, $\mathrm{H}=100 \mu \mathrm{m} ; \mathrm{B}-\mathrm{G}, \mathrm{I}-\mathrm{N}=20 \mu \mathrm{m}$. 
CEPEDA D. et al., Kinorhyncha from Skagerrak

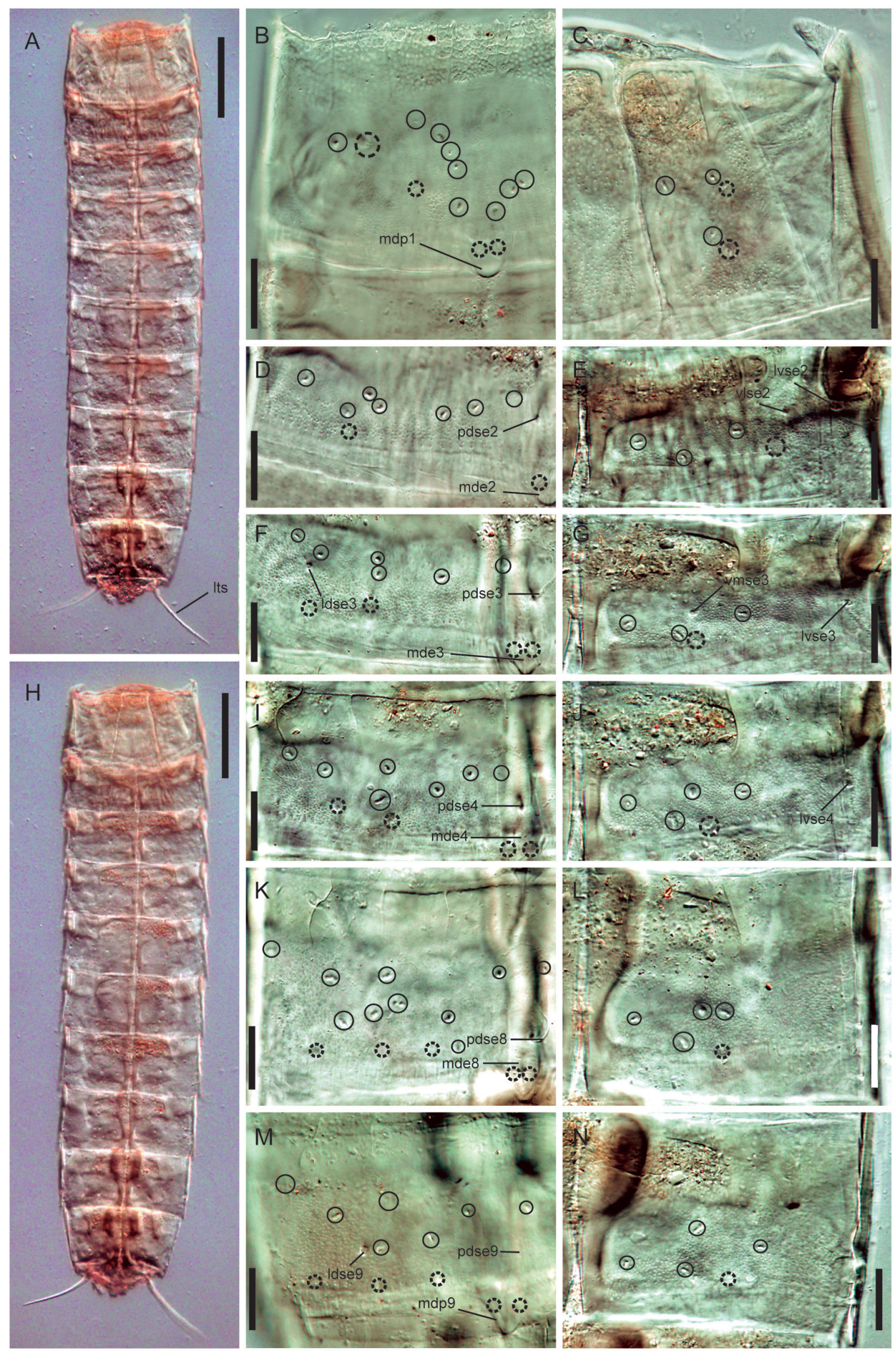




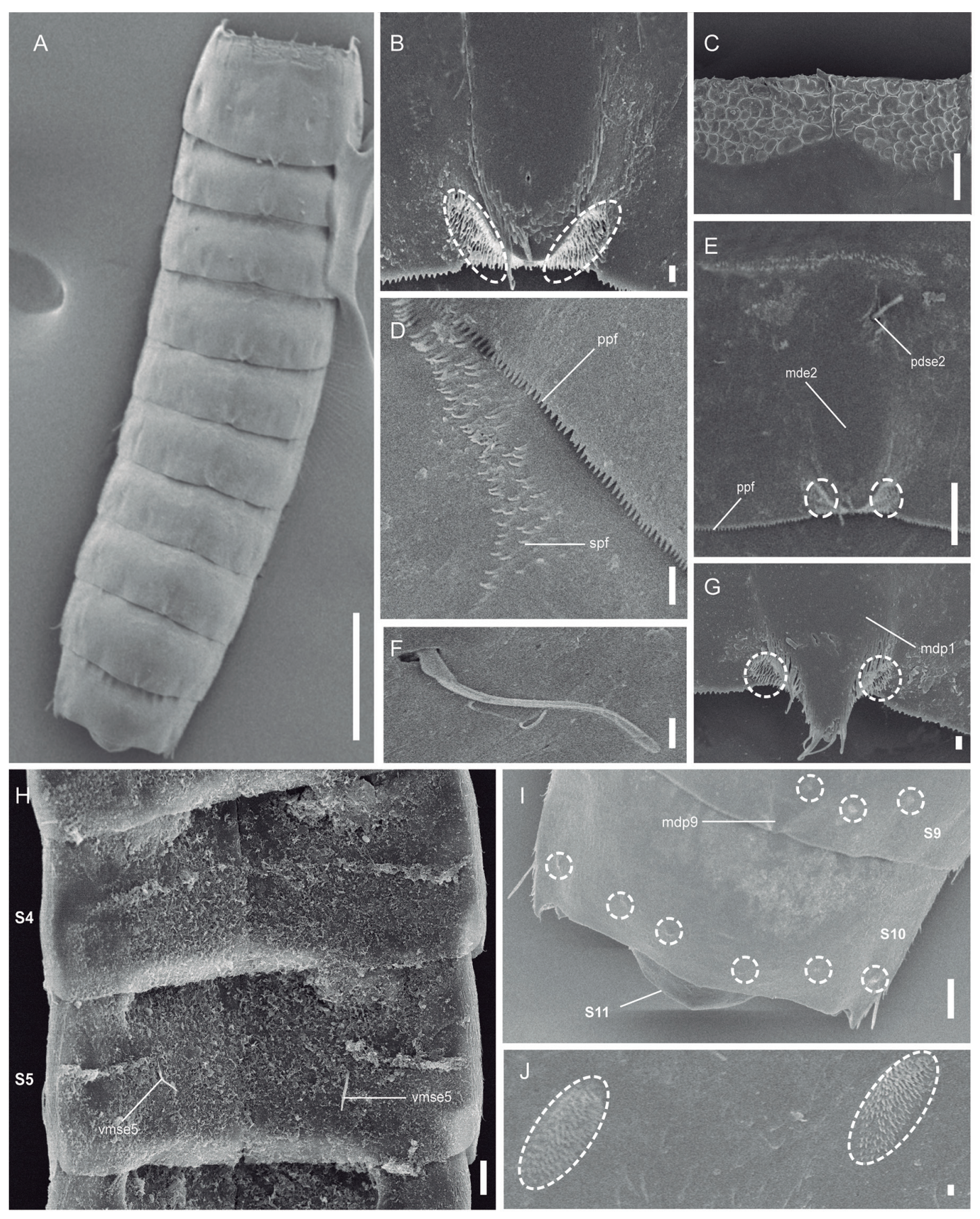

Fig. 4. Scanning electron micrographs showing general overview and details of the cuticular trunk morphology of a non-type specimen of Setaphyes elenae sp. nov. A. Dorsal overview. B. Middorsal elevation of segment 4. C. Cuticular ornamentation of anterior margin of segment 1. D. Detail of primary and secondary pectinate fringes of segment 5. E. Middorsal to paradorsal view of segment 2 . F. Laterodorsal seta of segment 5. G. Middorsal process of segment 1. H. Ventral view of segments 4-5. I. Dorsal view of segment 10 . J. Subdorsal sensory spots of segment 8 . Abbreviations: mde $=$ middorsal elevation; $\mathrm{mdp}=$ middorsal process; $\mathrm{pdse}=$ paradorsal seta; $\mathrm{ppf}=$ primary pectinate fringe; $\mathrm{s}=$ segment; vmse $=$ ventromedial seta. Numbers after abbreviations indicate corresponding segment; sensory spots are marked as dashed circles. Scale bars: $\mathrm{A}=100 \mu \mathrm{m} ; \mathrm{B}, \mathrm{D}, \mathrm{F}-\mathrm{G}, \mathrm{J}=1 \mu \mathrm{m} ; \mathrm{C}, \mathrm{E}, \mathrm{H}-\mathrm{I}=10 \mu \mathrm{m}$. 
Segment 3 with middorsal elevation as on the preceding segment (Figs 2B, 3F). Unpaired seta in paradorsal position (Figs 2B, 3F); paired setae in laterodorsal, lateroventral and ventromedial positions (Figs 2A-B, 3F-G). Paired sensory spots in paradorsal, subdorsal, laterodorsal and ventromedial positions, the latter mesially shifted compared to the previous ones, aligned with those of the following segments (Figs $2 \mathrm{~A}-\mathrm{B}, 3 \mathrm{~F}-\mathrm{G}$ ).

Segment 4 with middorsal elevation as on the preceding segment (Figs 2B, 3I, 4B). Unpaired seta in paradorsal position (Figs 2B, 3I); paired setae in lateroventral position (Figs 2A-B, 3J). Paired sensory spots in paradorsal, subdorsal, laterodorsal and ventromedial positions (Figs 2A-B, 3I-J).

Segment 5 similar to segment 3 in the arrangement of the cuticular elevation, setae and sensory spots (Figs 2A-B, 4F, H).

Segment 6 similar to segment 4 in the arrangement of the cuticular elevation, setae and sensory spots (Fig. 2A-B).

Segment 7 similar to segments 3 and 5 in the arrangement of the cuticular elevation, setae and sensory spots (Fig. 2A-B).

Segment 8 with middorsal elevation as on the preceding segment (Figs 2B, 3K). Unpaired seta in paradorsal position (Figs 2B, 3K); paired setae in lateroventral position (Fig. 2A-B). Two pairs of sensory spots in subdorsal position, and one pair in paradorsal, laterodorsal and ventromedial positions (Figs 2A-B, 3K-L, 4J).

Segment 9 with middorsal process as that of segment 1 (Figs 2B, 3M, 4I). Unpaired seta in paradorsal (Figs 2B and 3M); paired setae in laterodorsal and lateroventral positions (Fig. 2A-B). Two pairs of sensory spots in subdorsal position, and one pair in paradorsal, laterodorsal and ventromedial positions (Figs 2A-B, 3M-N, 4I). Nephridiopores in lateroventral position.

Segment 10 without middorsal cuticular specialization. Paired setae in lateroventral position (Figs 2AC, 4I). Two pairs of sensory spots in subdorsal position, and one pair in laterodorsal and ventrolateral positions, the latter near the tergosternal junction (Figs 2A-C, 4I).

Segment 11 without cuticular appendages, partly retractable into segment 10 (Fig. 4A, I). Tergal plate triangular, with a concave and distally pointed posterior margin; sternal plates form a pair of ventral extensions rounded distally (Figs 2A-C, 4I). Males with two sexually dimorphic pairs of stout, thick penile spines (Fig. 2C). Lateral terminal spines' length differs from males (relatively longer, LTS average ratio $=158.93 \mu \mathrm{m}$ ) to females (relatively shorter, LTS average ratio $=100.9 \mu \mathrm{m}$ )

\section{Discussion}

Setaphyes elenae sp. nov. clearly agrees with the main diagnostic characters of the genus, including the absence of ventrolateral setae on segment 5, the presence of unpaired paradorsal setae on segments 2-9 and paired lateroventral setae on segments $2-10$, ball-and-socket joints only conspicuous at segments 2-3 (reduced on posterior segments), and the presence of scattered, dot-shaped, intracuticular structures (sometimes called as cuticular scars) at both tergal and sternal plates (Sánchez et al. 2016). However, it can easily be distinguished from the remaining species of the genus by the unique arrangement of setae and middorsal cuticular specializations.

Regarding the seta arrangements, Setaphyes elenae sp. nov. has paired laterodorsal setae on segments 3, 5, 7 and 9, a pattern similar to that of $S$. dentatus and S. flaveolatus (Reinhard 1881; Zelinka 1928; Sánchez et al. 2016), with the exception that these congeners lack the setae on segment 9 . The remaining 
A

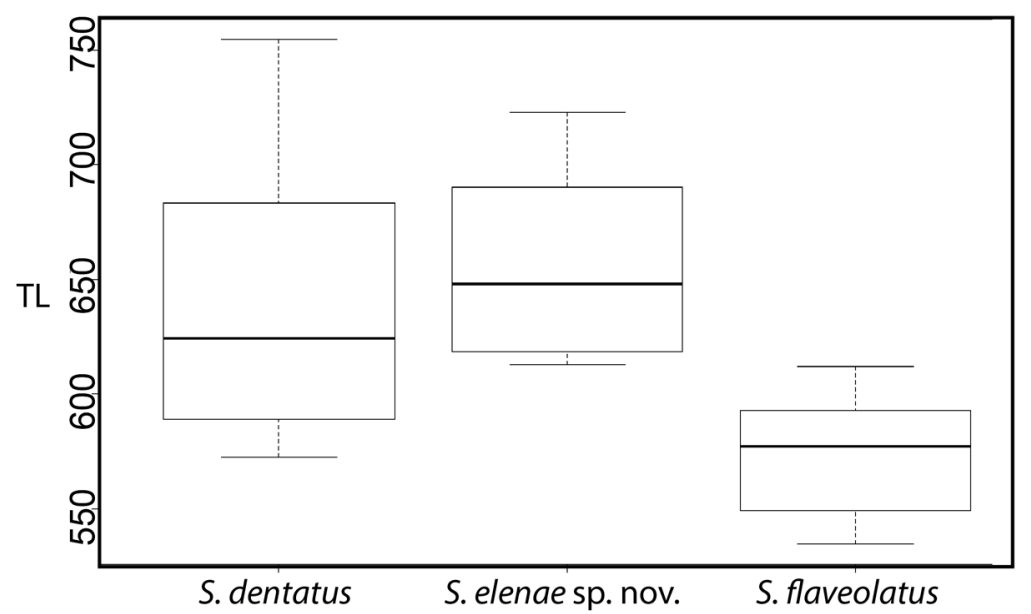

B

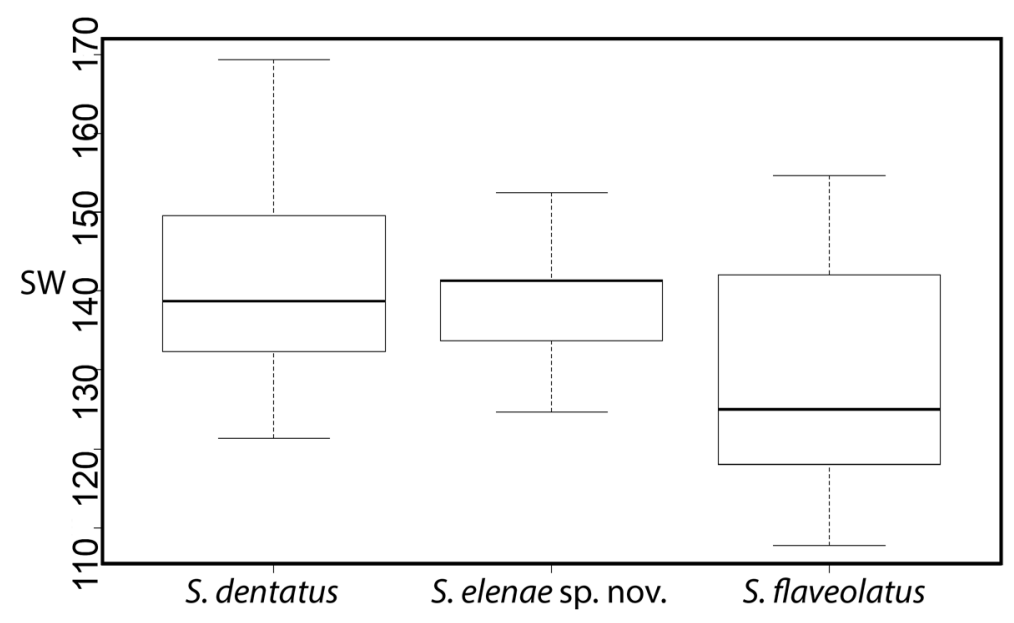

C

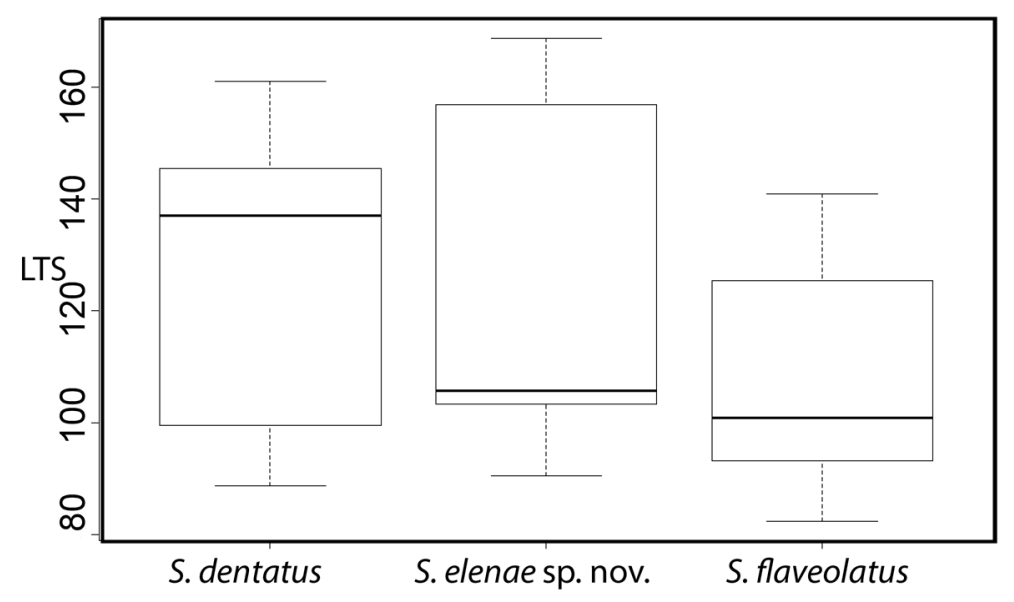

Fig. 5. Boxplots showing the ranges of different body measurements of Setaphyes elenae sp. nov., S. dentatus (Reinhard, 1881) and S. flaveolatus (Zelinka, 1928). A. Total trunk length. B. Standard sternal width. C. Lateral terminal spines' length. 
species of the genus also possess laterodorsal setae also even segments. In addition, S. elenae sp. nov. is characterized by bearing shortened, distally rounded middorsal processes on segments 1 and 9 exclusively, while both $S$. dentatus and $S$. flaveolatus have middorsal processes on segments 1 and 7-9. The pattern of ventromedial setae also differs between $S$. dentatus (on segments 4-5 and 7-9, females furthermore on segment 3), S. flaveolatus (on segments 5 and 7-8, females furthermore on segment 3) and $S$. elenae sp. nov. (on segments 3, 5 and 7).

Setaphyes cimarensis Sánchez et al., 2018, S. dentatus, S. elenae sp. nov. and S. flaveolatus are also characterized by having patterns of cuticular ornamentation that can be used to discriminate congeners (Sánchez et al. 2018). Longitudinal, parallel, fold-like cuticular thickenings are present on segment 10 in $S$. dentatus and S. cimarensis, which are absent in S. elenae sp. nov. and S. flaveolatus. Moreover, S. flaveolatus has a continuous, reticule-like ornamentation only present in the middle region of the tergal plate, whereas $S$. dentatus and $S$. elenae sp. nov. possess a similar ornamentation extended throughout the anterior margin of the plate, and S. cimarensis is characterized by having small, rounded, isolated depressions near the anterior margin of the plate with a net-like structure (Sánchez et al. 2018).

The only statistically significant differences were found in the total trunk length (TL) between Setaphyes elenae sp. nov. and $S$. flaveolatus $(p=0.00042$ ), so we can conclude that these two morphologically similar species may be also distinguished by the total trunk length (Fig. 5A). Oppositely, S. dentatus and $S$. elenae sp. nov. overlap, and statistically significant differences were not found $(p=0.51153)$ (Fig. 5A). Setaphyes flaveolatus is the smallest of the tested species, with a total trunk length of 500$600 \mu \mathrm{m}$, followed by $S$. dentatus and S. elenae sp. nov. with a total trunk length of 600-800 $\mu \mathrm{m}$ (Fig. 5A). The remaining analysed morphometric measurements were not significantly different between $S$. elenae sp. nov. and the aforementioned congeners (Fig. 5B-C).

\section{Acknowledgements}

We would like to thank Dr Ulf Jondelius from the Swedish Museum of Natural History (Stockholm) and Dr Fredrik Pleijel from the University of Gothenburg for organising the sampling expedition and taking the meiofaunal samples, and also to Nuria Rico Seijo for providing us the kinorhynch specimens for the present study. D. Cepeda was supported by a predoctoral fellowship of the Complutense University of Madrid (CT27/16-CT28/16).

\section{References}

Altenburger A. 2016. The neuromuscular system of Pycnophyes kielensis (Kinorhyncha: Allomalorhagida) investigated by confocal laser scanning microscopy. EvoDevo 7: 25.

https://doi.org/10.1186/s13227-016-0062-6

Cepeda D., Sánchez N. \& Pardos F. 2019. First extensive account of the phylum Kinorhyncha from Haiti and the Dominican Republic (Caribbean Sea), with the description of four new species. Marine Biodiversity 49: 2281-2309. https://doi.org/10.1007/s12526-019-00963-x

Curini-Galletti M., Artois T., Delogu V., De Smet W.H., Fontaneto D., Jondelius U., Leasi F., Martínez A., Meyer-Wachsmuth I., Nilsson K.S., Tongiorgi P., Worsaae K. \& Todaro, M.A. 2012. Patterns of diversity in soft-bodied meiofauna: dispersal ability and body size matter. PLoS ONE 7: e33801.

https://doi.org/10.1371/journal.pone.0033801

Fox J., Weisberg S., Price B., Adler D., Bates D., Baud-Bovy G., Bolker B., Ellison S., Firth D., Friendly M., Gorjanc G., Graves S., Heiberger R., Krivitsky P., Laboissiere R., Maechler M., Monette G., Murdoch D., Nilsson H., Ogle D., Ripley B., Venables W., Walker S., Winsemius D., Zeileis A. \& R Core Team. 2019. Package 'car'. Ver. 3.0-5. https://r-forge.r-project.org/projects/car/ 
Gerlach S.A. 1969. Cateria submersa sp. n., ein cryptorhager Kinorhynch aus dem sublitoralen Mesopsammal der Nordsee. Veröffenlichungen des Instituts für Meeresforschung in Bremerhaven 12: $161-168$.

Higgins R.P. 1988. Kinorhyncha. In: Higgins R.P. \& Thiel H. (eds) Introduction to the Study of Meiofauna: 328-331. Smithsonian Institution Press, Washington D.C.

Huys R. \& Coomans A. 1989. Echinoderes higginsi sp.n. (Kinorhyncha, Cyclorhagida) from the southern North Sea with a key to the genus Echinoderes Claparède. Zoologica Scripta: 18: 211-221. https://doi.org/10.1111/j.1463-6409.1989.tb00446.x

McIntyre A.D. 1962. The class Kinorhyncha (Echinoderida) in British waters. Journal of the Marine Biological Association of the United Kingdom 42:503-509. https://doi.org/10.1017/S0025315400054217

McIntyre, A.D. 1964. Meiobenthos of sub-littoral muds. Journal of the Marine Biological Association of the United Kingdom 44 (3): 665-674. https://doi.org/10.1017/S0025315400027843

Mora C., Tittensor D.P., Adl S., Simpson A.G.B. \& Worm B. 2011. How many species are there on Earth and in the Ocean? PLoS Biology 9: e1001127. https://doi.org/10.1371/journal.pbio.1001127

Neuhaus B. 2013. Kinorhyncha (= Echinodera). In: Schmidt-Rhaesa A. (ed.) Handbook of Zoology. Gastrotricha, Cycloneuralia and Gnathifera. Volume 1: Nematomorpha, Priapulida, Kinorhyncha, Loricifera: 1-69. De Gruyter, Göttingen. https://doi.org/10.1515/9783110272536

Neuhaus B., Pardos F. \& Sørensen M.V. 2013. Redescription, morphology and biogeography of Centroderes spinosus (Reinhard, 1881) (Kinorhyncha, Cyclorhagida) from Europe. Cahiers de Biologie Marine 54: 109-131. https://doi.org/10.21411/CBM.A.8E3FD0CA

Nyholm K.G. 1947. Studies in the Echinoderida. Arkiv för Zoologi 39: 1-36.

Reinhard W. 1881. Über Echinoderes und Desmoscolex der Umgebung von Odessa. Zoologischer Anzeiger 4: 588-592.

Rodhe J. 1996. On the dynamics of the large-scale circulation of the Skagerrak. Journal of Sea Research 35: 9-21. https://doi.org/10.1016/S1385-1101(96)90731-5

Rosenberg R., Cato I., Förlin L., Grip K. \& Rodhe J. 1996. Marine environment quality assessment of the Skagerrak-Kattegat. Journal of Sea Research 35: 1-8. https://doi.org/10.1016/S1385-1101(96)90730-3

Sánchez N., Herranz M., Benito J. \& Pardos F. 2012. Kinorhyncha from the Iberian Peninsula: new data from the first intensive sampling campaigns. Zootaxa 3402: 24-44.

https://doi.org/10.11646/zootaxa.3402.1.2

Sánchez N., Yamasaki H., Pardos F., Sørensen M.V. \& Martínez A. 2016. Morphology disentangles the systematics of a ubiquitous but elusive meiofaunal group (Kinorhyncha: Pycnophyidae). Cladistics 32: 479-505. https://doi.org/10.1111/cla.12143

Sánchez N., García-Herrero A., García-Gómez G. \& Pardos F. 2018. A new species of the recently established genus Setaphyes (Kinorhyncha, Allomalorhagida) from the Mediterranean with an identification key. Marine Biodiversity 48 (1): 249-258. https://doi.org/10.1007/s12526-017-0651-1

Sørensen M.V. \& Grzelak K. 2018. New mud dragons from Svalbard: three new species of Cristaphyes and the first Arctic species of Pycnophyes (Kinorhyncha: Allomalorhagida: Pycnophyidae). PeerJ 28: e5653. https://doi.org/10.7717/peerj.5653

Sørensen M.V. \& Pardos F. 2008. Kinorhynch systematics and biology - an introduction to the study of kinorhynchs, inclusive identification keys to the genera. Meiofauna Marina 16: 21-73. 
Sørensen M.V., Heiner I. \& Hansen J.G. 2009. A comparative morphological study of the kinorhynch genera Antygomonas and Semnoderes (Kinorhyncha, Cyclorhagida). Helgoland Marine Research 63: 129-147. https://doi.org/10.1007/s10152-008-0132-9

Sørensen M.V., Rho H.S., Min W.G., Kim D. \& Chang S.Y. 2013. Occurrence of the newly described kinorhynch genus Meristoderes (Cyclorhagida: Echinoderidae) in Korea, with the description of four new species. Helgoland Marine Research 67 (2): 291-319. https://doi.org/10.1007/s10152-012-0323-2

Weering T.C.E., Berger G.W. \& Kalf J. 1987. Recent sediment accumulation in the Skagerrak, Northeastern North Sea. Netherlands Journal of Sea Research 21: 177-189.

https://doi.org/10.1016/0077-7579(87)90011-1

Weering T.C.E., Rumohr J. \& Liebezeit G. 1993. Holocene sedimentation in the Skagerrak: a review. Marine Geology 111: 379-391. https://doi.org/10.1016/0025-3227(93)90142-I

Zelinka C. 1928. Monographie der Echinodera. Engelmann, Leipzig.

Manuscript received: 4 December 2019

Manuscript accepted: 16 March 2020

Published on: 29 April 2020

Topic editor: Rudy Jocqué

Desk editor: Pepe Fernández

Printed versions of all papers are also deposited in the libraries of the institutes that are members of the EJT consortium: Muséum national d'histoire naturelle, Paris, France; Meise Botanic Garden, Belgium; Royal Museum for Central Africa, Tervuren, Belgium; Royal Belgian Institute of Natural Sciences, Brussels, Belgium; Natural History Museum of Denmark, Copenhagen, Denmark; Naturalis Biodiversity Center, Leiden, the Netherlands; Museo Nacional de Ciencias Naturales-CSIC, Madrid, Spain; Real Jardín Botánico de Madrid CSIC, Spain; Zoological Research Museum Alexander Koenig, Bonn, Germany; National Museum, Prague, Czech Republic. 